Journal of Social and Development Sciences

Vol. 2, No. 4, pp. 181-187, Oct 2011 (ISSN 2221-1152)

\title{
International Forced Migration and Pak- Afghan Development Concerns: Exploring Afghan Refugee Livelihood Strategies
}

\author{
Rehan Khan Muhammad \\ Iqra University Islamabad Pakistan \\ Rehankhan82@gmail.com
}

\begin{abstract}
This study investigates the livelihood strategies employed by Afghan refugees residing in Pakistan. These refugees were forced to take refuge in Pakistan after Soviet Union invaded Afghanistan in 1978. Three decades after their migration, and after repeated Pakistani government attempts to resettle them in Afghanistan, scores of Afghan refugees still reside in Pakistan. This paper discusses the evolving relationship between Afghanistan and Pakistan over the years and their respective implications. Researching the various livelihood strategies that Afghan refugees pursued their impact on the Pakistani labor market is discussed. By means of taking a case study of an Afghan refugee woman, this study concludes that there exists a gender dimension in Afghan refugee population. In doing so two developmental concerns are identified i) development projects focused on refugee assistance in Afghanistan and Pakistan ignore the development concerns of the women population ii) countries that provide refuge to victims of war are exposed to a new set of development challenges in addition to their already burdened economy. This paper furthers the academic debate on achieving the development challenge of attaining a stable South Asia, in light of the AfPak strategy initiated by President Obama in 2010, and reflects on potential areas for policy making for Pakistan, Afghanistan and the United States.
\end{abstract}

Keywords: Refugees, Forced migration, Livelihood strategies, Development,Gender.

\section{Introduction}

International Forced migration and refugees are emerging areas for academic discourse. This essay seeks to explore the livelihood strategies employed by Afghan refugees who were the victims of international forced migration. The urgency of this research is greater than ever as i) the conflict in Afghanistan has been little understood, especially when the county's past has had strong impacts on the livelihoods of the Afghans ii) the emerging reconstruction plans in Afghanistan post 9/11 give increased emphasis to the livelihood strategies of the Afghans (Pain, 2002). Research carried out by the Institute of Policy Studies Islamabad (n.d.). suggests that this issue holds exigent importance to policy makers of Pakistan, as the estimated 3 million Afghan refugees increase the socio-economic burdens of the country. The impact of this socio-economic burden also impacts neighboring Afghanistan. Evidence comes from Kfir (2010) who analyzes the US policy for Afghanistan and Pakistan, termed as AfPak, under the Obama administration. He reflects upon the impact that both Afghanistan and Pakistan exert on each other's development priorities. In this scenario, this research addresses livelihood strategies of Afghan refugees in Pakistan. Furthermore, it poses policy considerations and implications for Pakistan and Afghanistan, as well as for the US in bridging the gap towards bringing stability to the South Asian region.

This paper contextualizes the debate around the forced movement of Afghans into Pakistan. The discussion briefly locates the origins of the Afghan refugee crisis as a result of the soviet invasion of Afghanistan in 1979. The exodus of Afghans following this intervention is discussed in its socio-cultural context (Fielden, 1998) while touching at the geo-political reasons why Pakistan became the asylum country with the largest number of refugees worldwide (UNHCR, 2006). By exploring the changing stance of the Government of Pakistan due to the cessation of international aid for refugees, the essay will focus on the livelihood strategies employed by Afghan refugees. The discussion will reach its focal point as the role of the Afghan women refugees will be elaborated in this scenario. For this purpose, a case study of an Afghan women refugee in Pakistan will be incorporated into the paper, which will elaborate a gender dimension to the Afghan refugees in Pakistan. 
The latter part of the essay will delve into the conflicts of interest that arise between the host and the refugee community, in this case Pakistan and Afghanistan respectively. There is an amount of academic literature that discusses the gender dimensions of Afghan women refugees in Pakistan and the aid programs that focus towards their needs. This paper attempts to elaborate and identify the developmental challenges in such a situation and provide a starting point for policy makers to make development equitable and sustainable. Towards its conclusion, the essay will discuss development concerns that have arisen out of a scenario where Afghan migrants are forced out of their country, whose socio-economic indicators lie near the bottom of the world rankings (Kronenfeld, 2008), into an already susceptible and politically unstable Pakistan (Kfir, 2010). Mass expulsion is a form of forced migration that are instigated by the government on its people (Hear, 1998). According to "Forced Migration Online" (n.d.), forced migration is defined as "the use of coercion, including a variety of political, economic and social measures which directly or indirectly force people to flee their homelands for fear of life, liberty and security and forcing the departure of persons against their will". Forced migration is related to systematic changes at a world level and has a global dimension to it. Attempts to understand the political, economic and social developments must be taken into account to understand forced migration (Marfleet, 2006). Conflict induced displacement is a type of forced migration that can be attributed to Afghanistan where millions of Afghans fled to neighboring Pakistan due to Soviet occupation of Afghanistan in 1979 (Ruiz \& Emery, 2001).

Although migration between Afghanistan, Pakistan and Iran has been an ongoing historical phenomenon (Monsutti, 2008), it was forced migration for the Afghanis to flee to Pakistan in millions, as the Soviet occupation intensified. As the typical Afghan family is a closely knit unit, Afghan Research and Evaluation Unit (2006) reports that in these testing times Afghans fell back on their strong family ties for support. Relying on informal social networks to survive, the Afghans were able to come to cities by seeking out tribal connections (AREU, 2006b).

Response of Government of Pakistan to the Afghan Influx: Grare (2003) argues that Pakistan gave refuge to Afghani's because there was a global affinity for Afghans in the world. It wanted to benefit from the situation and advance its own geo-political agenda. Pakistan has an unstable government and was threatened by an arch Indian rival on one border while a warring Afghanistan on the other. An alternative view is given by Walzer (2008) who holds Pakistan's decision to extend hospitality to the Afghans as a genuine one that was supported by all levels of the population.

The refugee policies of the host government, or in case where central government is weak, is a key determinant of refugee's vulnerability and their ability to pursue livelihoods (Jacobsen,2002). It seems that the response of the Government of Pakistan (GoP) towards Afghan refugees has evolved with time. The Afghan forced migrants were accommodated on the Pakistan -Afghanistan border. Even though Pakistan has its own border restrictions Afghans refugees still entered into Pakistan without completing formalities (Khan, 2006 as cited in Conference on Afghan Population Movement, 2006). The GoP announced its intentions to extend the Proof of Registration cords for Afghans from December 2009 to December 2012 and to implement the strategy for the management of Afghans (UNHCR Global Report 2009).

As the GoP is not party to the 1951 Refugee Convention or the 1967 Protocol, with no national refugee laws in place, UNHCR's role became more vital to assist with Afghan refugees (UNHCR Global Report 2009). UNHCR carried out its largest operation regarding Afghan refugees in reply to the GoP cry for help in managing a rising influx of Afghan asylum seekers (Walzer, 2008). These refugees were provided with tents, food, health and educational centres. They were also permitted to seek employment within Pakistan with certain restrictions (Marsden, 1999). By the year 2006, Pakistan had hosted more than 3.5 million Afghans (Khan, 2006 as cited in AREU,2006 c). However, the accommodating stance of the GoP changed with time.

Earlier, in the 1990's the international aid given to Pakistan to deal with its Afghan refugees stopped. At this time the GoP displayed a hardening attitude to its two million Afghan refugees. Discussing the response of the GoP, Ruiz and Emery (2001) advocate that the GoP wanted the refugees to return to Afghanistan as the Soviet invasion of Afghanistan had ended. GoP also blamed Afghan refugees for increased crime, drug use and prostitution. When left to deal with Afghans refugees on its own, the Government faltered. This was reflected in Pakistan's border closings and attempts to close long term camps. 
Interestingly on a local level, in cities like Peshawar (an urban centre in the province of Khyber Pukhtunkhwa, in Pakistan) the Afghan forced migrants were recognized as part of the community (AREU, $2006 \mathrm{a}$ ). Yet, these refugees often outnumbered the local population, who had to share their livelihoods and resources. As labor conditions have also been a dominant factor in how the locals receive refugees (Chambers, 1986), conflicts amongst the refugees and host communities started to occur (These will be discussed in the due course of this paper). Sustainable livelihood approaches need to be adapted to the victims of forced migration. Refugees pursue livelihoods in refugee camps or outside them by engaging in activities considered illegal. These forced migrants move in between these two livelihood domains, using resources from both, and mixing their livelihood strategies accordingly. This can have mixed ramifications for the refugees and hosts community (Jacobson, 2002).

In the case of Afghan forced migrants, they had varying livelihood strategies to generate economic activity for survival. Discussing in detail the livelihood strategies of Afghan refugees, Afghan Research and Evaluation Unit (2006a, 2006b, Conference on Afghan population movement, 2006) explains that these forced migrants displayed diverse livelihood activities including wage labor, carpet-weaving, the timber trade, retail and wholesale markets, transport as well as employment with the religious organizations. The livelihood strategies employed by the refugees were directly related to the level of skill and education they had. Generally, the income range for the refugees varied from $\$ 50$ to $\$ 400$ a month. However, a large majority fell at the lower end of the income scale. The low end refugees, with minimal or no education or skill, resorted to either begging, working as daily wage workers or as petty vendors to meet their economic needs. In other refugee camps refugees also worked as unskilled construction workers. The Afghan Research and Evaluation Unit that a seasonal niche activity in some refugee camps was connected to timber trade also observed it. Workers from these refugee camps were hired by contractors to harvest timber in pre-determined areas. The wood is brought back to timber yards and sawmills in the same refugee camps where it was sorted, and sold onwards as construction material and firewood (AREU,2006a).

Gender dimension in refugee assistance: A development challenge: In Afghanistan, men are responsible for providing for their families needs (Hoodfar, 2009). However, displacement exaggerates unequal relations of gender where customary resources are denied to women, who are made more vulnerable (Marfleet, 2006). Yet even thou the Afghan women, lacking the opportunity to be active in the public sphere (Hoodfar, 1996 as cited Hoodfar, 2009; Hoodfar, 1997) were still eager to participate in income generating activities (Dutch Interchurch Aid, 1990). However, ethnicity of the Afghan refugee women also seemed to be an influencing factor. Ethnic Pashtun women do not venture out of their homes, whereas women of Tajik origin work as carpet weavers or as domestic staff (AREU,2006 a).

In the authors personal experience an Afghan refugee woman of Tajik ethnicity, Noor bibi, has been working as a domestic servant in his family for almost thirty years. Noor bibi escaped from Afghanistan in 1979 due to the Soviet occupation of Afghanistan. After losing her agricultural land and house in Afghanistan, Noor bibi and her family were forced to migrate into Pakistan. Soon after their migration into Pakistan Noor bibi's husband became a drug addict and was economically inactive. In order to feed her family of eleven children, she took up the responsibility of earning for the family. Noor bibi was not educated and had not developed professional skills. She ventured out of her refugee camp and managed to find work as a domestic servant in the authors family in the city of Peshawar. In line with the Government of Pakistan's initiative to send the Afghan refugees back to their native land, her family tried to resettle in Afghanistan, however, she always ended up back at the authors house for work. The economic conditions in Afghanistan were not feasible to make a living as economy generating activities were hard to come by. Noor bibi's son, who grew up beside the author, today engages in alternating economic generating activities like timber trade, driving public transport vehicles and working as a vendor to generate a livelihood for himself. Noor bibi has now moved out of the refugee camp and lives in a house made of mud and bricks.

Afghan Research and Evaluation Unit observe that refugees living in mixed Afghan-Pakistani sub-sites were clearly better off as compared to those living in designated refugee camps and irregular settlements. Selfemployment in various sectors - notably carpet-making - was the most important source of livelihood there and involved higher levels of skill and investment. Afghan refugees who had Turkmen ethnicity employed a 
more traditional livelihood strategy. The refugee family units of these refugees, on fleeing Afghanistan, engaged in their traditional livelihood strategies of carpet weaving in order to meet their economic needs. Besides these niche sectors, Afghans generally operated in the same sectors and activities as the host population (AREU, 2006 a). With time, refugees that had settled well in Pakistan after the forced migration, were observed to start Afghan educational institutes and English language training centers. These institutions employed only Afghans, usually Afghan women. There appears to have been a major transformation in the economic profile of Afghan refugees and migrants after their arrival in Pakistan - away from agricultural and rural activities and towards non-agricultural sectors including construction, transport, trade and other service sectors(AREU,2006 a).

As revealed by the Population Census (2005), and by the qualitative work undertaken by Afghan Research and Evaluation Unit, casual wage labor was one of the most important sources of livelihoods for Afghans. Gazdar (2004) advocates for this position and holds that the casual labor implies a bottom-line activity with minimal use of physical, financial, human or social capital. Reliance on casual labor signals the absence of other, more remunerative, economic opportunities. Amidst this debate on refugee livelihood strategies, it is worth noticing here that international support may not have targeted refugee women in their aid programs. Khan, (2002) as cited in (AREU, 2006 a) reveals that the donor community did not see the need to target the special needs of the refugee women to make them economically active. This may be due to the fact that equitable distribution of program benefits are hindered by religion and traditional constraints and inhibit women from benefiting from the aid program, as is in the case of Afghan women refugees (AREU,2006 b). Working odd, low paid jobs was a lifeline for the refugees that created a new set of developmental challenges for the host country.

It was believed that Pakistanis were "priced out" of many sectors and activities (AREU, 2006 a). The Ministry of Labor of Pakistan (2004) makes a closer examination of the types of jobs that Afghans took up and discusses that Afghans made inroads into some of the most marginalized activities, such as rag-picking. Afghans also began to appear in sectors such as brick-making which were formerly the preserve of socially marginalized Pakistani communities. This had a potential for a cultural transformation as tensions and conflicts amongst the refugee and host communities arose (Walzer, 2008). Although, much of the local welcome to rural refugees can be attributed to benefits from the cheap labor and farming activities that they provide (Chambers, 1979 ; Kibraeb, 1983) yet on a local level refugee livelihoods are affected by the host community and the local administrations. As outsiders, the refugees have to rely on the goodwill of the local population to successfully integrate in the society and have access to livelihoods (Jacobson, 2005).

Development challenges of International Forced Migration: The effects of refugee influxes cause problems for the refugees as well as the host community. An example can be the additional strain put by Afghan refugees put on food supplies as well on the services available to the local Pakistani population. This in turn exacerbates the problems of an already economically fragile country like Pakistan. The situation becomes bleak if the host country is experiencing a drought (Betts, 1980). The sheer numbers and prolonged stay of refugees in Pakistan adversely affected the infrastructure and environment of Pakistan. Entire forests disappeared as refugees searched for fire wood to use primarily as burning fuel. In addition, roads and traditional water systems were used to the point of breaking down (Walzer, 2008). A number of development lessons emerged from the refugee crisis of Afghanistan and Pakistan. This identified areas in which development efforts needed to be concentrated on. Suhrke (1993) discusses that the horrific statistics on Afghan refugees demanded immediate action for income generation, education and training especially for Afghan women. It was difficult for the aid community to reach the Afghan women in the refugee villages. This was so because of the restricted movements of women due to traditional limitations. The following comment given by an Afghan refugee woman highlights this issue.

"We have been left out of programs, education and skill building. We have lost everything and are returning to Afghanistan with empty hands and nothing to offer" (Cammack, 1995). Jacobson (2002) explains a second development concern. He holds that forcibly displaced from their home countries, people move across borders to neighboring countries. Yet many of these neighboring countries are already facing their own conflicts. The influx of refugees only puts economic, environmental and security burdens on their hosts. This 
seems to be the situation in the case of Afghanistan and Pakistan. For Pakistan, where land is scarce and labour is relatively abundant, this means that the poorer segment of the Pakistani population can lose from the increased competition for food, work, wages, services and common property resources (Chambers, 1986). Christensen (1984) while giving a contrasting view argues that refugees provide local farmers with labour, and allows the farmers to expand their agricultural productivity. Yet majority of the poorer hosts may not be able to employ refugee labour at all.

Johnson (1979) discusses that refugees can hurt hosts who rely on laboring for all parts of their livelihoods. Furthermore, refugee influx does depress daily wage rates. This means that any agricultural schemes operating near refugee camps, pay excessively low wages to its mainly women and children workers. When such circumstances come into play, it causes spiking differences between the host community and the refugees. Christensen (1983) who explains in the case of Pakistan how the host community turned away the refugees from available employment opportunities has documented evidence of this. They justified their actions by arguing how the refugee populace had priced them out of the labor market. It has also been found that food aid to refugees, in such a situation, can have the unintentional affect of supporting poor subsidized people against poor unsubsidized people. This adds additional burden on the local Pakistani community as well as the existing health and educational institutions. Discussing the services provided for refugees through sharing schools and health centres of hosts, Harrell-Bond sheds (1985) believes that an increased influx of refugee population puts acute pressure on the services sector as well. In the case of health centres, drugs and treatment can become harder to obtain. Similarly, the pressure on educational institutions also increases.

\section{Discussion and Conclusion}

The problem of Afghan refugees in Pakistan has emphasized the need for enhanced development assistance that is also sustainable in the long run. Humanitarian assistance for displaced people can and should include both emergency relief inputs and long term livelihood support. The latter is most efficacious when it is aimed at both displaced people and the host community (Jacobson, 2002). Secondly, the Afghan experience demonstrated that women's roles and issues must be clearly defined and incorporated into policies, plans and institutional changes at all levels in order to increase women's productivity, improve their health and educational standards (Cammack, 1995) and in the process make development more equitable.

Thirdly, in the past Pakistan has been among the top aid recipient countries of development assistance from various donor agencies, as well as from the United States. The United States alone from 1948 onwards has given aid assistance to Pakistan exceeding 30 billion US dollars, half of which was military aid (The Guardian, 2011). Herein lays increasing responsibility of donor agencies to effectively plan the delivery of development aid so as to make it equitable, sustainable and case sensitive. Development assistance must be an everlearning mechanism that in light of the Afghan migration should link development assistance with gender sensitivity at the planning and execution phases as well as to protect the needs of the host country. This may be achieved by taking into consideration the culture, religion and local knowledge of the area and amalgamating them into policy making environment.

Fourth, the asylum providing countries should undertake measures to take into account the threat of illegal activities that may arise when victims of forced migration explore livelihood strategies that may be considered illegal in the host country. This factor may be addressed by drawing upon effective policy planning to contain illegal employment strategies. Failure to do so may result in harming not only the refugees but also the host communities and their Governments as well. This is reflected in the case of Afghanistan and Pakistan, where millions were rendered homeless in the wake of Soviet invasion of Afghanistan in 1978 (Ellis, 1998). For Pakistan and the development community at large, these measures will result in curbing of illegal activities like theft, prostitution, drug use and human trafficking. The findings of this paper also identify a set of policy making concerns for violence prone regions of the globe, that are susceptible to international forced migration. Mass movement of population across international borders not only burdens the economy, but fluctuates the wage rates of country as well. If left unchecked this may well make the Millennium Development Goal of eradicating poverty even more challenging. 


\section{References}

Afghan Research and Evaluation Unit (2006 b, January). Afghans in Peshawar: Migration, Settlement and Social Networks. Case study series, Collective for social science research. Kabul, Afghanistan: Author.

Afghan Research and Evaluation Unit. (2006a, January). Afghans in Quetta: Settlement, Livelihoods, Support Networks and Cross border linkages. Case study series, Collective for social science research. Kabul, Afghanistan: Author.

Betts, T. F. (1980). Consequences of the drought in Bas Zaire, 1978. Disasters, 4(1), 55-64.

Cammack, D. (1995). Development and forced migration: Case of Afghan refugee women in Pakistan. In R. Cohen (Ed.). The Cambridge survey of world migration (461-465). New York: Press Syndicate of the University of Cambridge.

Chambers, R. (1979). Rural refugees in Africa: what the eye does not see. Disasters, 3(4), 381-392.

Chambers, R. (1986). Hidden losers? The impact of rural refugees and refugee programs on poorer hosts. International Migration Review, 20(2), 245-263.

Christensen, H. (1983). Sustaining Afghan refugees in Pakistan: A report on the food situation and related social aspects. Geneva: United Nations Research Institute for Social Development. Retrieved July 28, 2010, from: http://repository.forcedmigration.org/show_meta data.jsp?pid=fmo:3216

Christensen, H. (1984). Afghan Refugees in Pakistan: From emergency towards self reliance. A report on the food relief situation and related socio economic aspects. Geneva: United Nations Research Institute for Social Development. Retrieved July 28, 2010, from:

Conference on Afghan Population Movement. (2006, February 14). Afghan Research and Evaluation Unit. Retrieved July 28, 2010, from:

Dutch Interchurch Aid. (1990, November). Travel report Pakistan. Islamabad, PK: Author.

Ellis, F. (1998). Household strategies and rural livelihood diversification. Journal of development studies, 35(1), 1-38.

Fielden, M. B. (1998). The Geo-politics of aid: the provision and termination of aid to Afghan refugees in North West Frontier Province, Pakistan. Political Geography, 17(4), 459-487.

Forced Migration Online. (n.d.). Retrieved August 8, 2010, from http://www.forcedmigration.org/whatisfm.htm.

Gazdar, H. (2004). Labour Markets and Poverty in Pakistan: Institutional Arrangements and Policy Working Paper. Islamabad: ILO, CRPID and UNDP.

Grare, F. (2003). The geopolitics of Afghan refugees in Pakistan. In Stedman, S.J \& Tanner, F (Eds.). Refugee Manipulaiton : War politics and the abuse of human suffering (57-94). Washington: Brookings Institute press.

Harrell-Bond, B. (1985). Imposing Aid: Emergency Assistance to Refugees. New York: Oxford University Press.

Hear, N. V. (1998). New Diasporas : The mass exodus, dispersal and regrouping if migrant communities. Seattle: University of Washington Press.

Hoodfar, H. (1997). Between Marriage and the Market: Intimate politics and survival in Cairo. Berkeley and Los Angeles: University of California Press.

Hoodfar, H. (2009). Afghan refugee women in Iran. In Cuno, K.M \& Desai, M (Eds.). Family, Gender \& law in a globalizing Middle East and South Asia (223-250). New York: Syracuse University Press.

http://www.google.co.nz/\#hl=en\&q=Hanne+Christensen\%2C+1984.+Sustaining+Afghan+refugees+in+Pakis $\tan \% 3 \mathrm{~A}+\mathrm{A}+$ report+on+the+food+situation+and+related + social+aspects\&aq=o\&aqi $=\& a q l=\& o q=\& g s \_r f a i=\& f p=9782 a 080 f 5 e b 2 a 8 f$

Institute of Policy Studies (n.d.) Afghan Refugees in Pakistan Current Situation and Future Scenario. Policy Perspectives (3) 2. Accessed: http://www.ips.org.pk/the-muslim-world/1023-afghan-refugees-inpakistan-current-situation-and-future-scenario.html

Jacobsen, K. (2002). Livelihoods in conflict: The pursuit of livelihoods by refugees and the impact on the human security of host communities. International Migration, 40(5), 95-123. 
Jacobson, K. ( 2005). The economic life of refugees. In Beyond the country of First Asylum: Refugees in third world countries (.53-68). Bloomfield: Kumarian Press.

Johnson, T. (1979). Eritrea refugees in Sudan. Disaster, 3(4), 417-421.

Kfir, I. (2010). US policy toward Pakistan and Afghanistan under the Obama administration. Retrieved from http://www.weeklyblitz.net/441/us-policy-toward-pakistan-and-afghanistan-under

Khan, M. I. (2006). Key challenges and policy options for managing cross border population movements. In Proceedings for the Conference on Afghan Population Movements. Islamabad, Pakistan: Afghan Research and Evaluation Unit.

Kibraeb, G. (1983). Reflections on the African Refugee problem: A critical analysis of some basic assumptions. Working paper. Uppsala: Scandinavian Institute of African Studies.

Kronenfeld, D. A. (2008). Afghan refugees in Pakistan: Not all refugees, not always in Pakistan, not necessarily Afghan. Journal of Refugee Studies, 21(1), 44-63.

Marfleet, P. (2006). Refugees in a global era. New York: Palgrave Macmillan.

Marsden, P. (1999). Repatriation and reconstruction: The case of Afghanistan. In Balck, R \& Koser, K (Eds.). The end of the refugee cycle? Refugee repatriation and reconstruction (56-68). New York: Berghahn Books.

Ministry of Labor (2004). Labor, debt and bondage in brick kilns in Pakistan. Islamabad, PK: Author.

Ministry of States and Frontier Regions (2005). Census of Afghans in Pakistan 2005. Islamabad, PK: Author.

Monsutti, A. (2008). Afghan migratory strategies and the solutions to the refugee problem. Refugee Quarterly Survey, 27(1), 58-73.

Pain, A. ( 2002). Understanding and monitoring livelihoods under conditions of chronic conflict : Lessons from Afghanistan. Overseas Development Institute. London : UK.

Ruiz, H., Emery, M. (2001). Afghanistan's refugee crisis. Retrieved July 28, 2010, from http://www.merip.org/mero/mero092401.html.

Suhrke, A. (1993). Refugees and asylum in the muslim world. In In R. Cohen (Ed.). The Cambridge survey of world migration (457-460). New York: Press Syndicate of the University of Cambridge

The Guardian (2011). Sixty years of US aid to Pakistan : Get the data. Accessed from http://www.guardian.co.uk/global-development/poverty-matters/2011/jul/11/us-aid-to-pakistan

United Nations High Commission for Refugees. (2006). Global trends: Refugees, asylum seekers, returnees, internally displaced and stateless persons. Geneva, Switzerland: Author.

United Nations High Commission for Refugees (n.d.). Retrieved from http://www.unhcr.org/4c08f2939.html Walzer, G. (2008). UNHCR Operations in Pakistan in the early 1980's. Refugee Survey Quarterly, 27(1), 40-44. 